\title{
SISTEM AGRIBISNIS DAN RANTAI PERSEDIAAN CABAI DI PEKANBARU
}

\author{
Agribisnis System and Supply Chain Chilli In Pekanbaru
}

\author{
Mukhtar Ahmad $^{1}$ Febriska $^{3}$ dan Darus ${ }^{2}$ \\ Pusat Kajian Pembangunan Berkelanjutan, Universitas Islam Riau, Pekanbaru, Riau. \\ 2 Dosen Agribisnis, Fakultas Pertanian, Universitas islam Riau, Pekanbaru, Riau. \\ Jurusan Agribisnis, Fakultas Pertanian, Universitas islam Riau, Pekanbaru, Riau.
}

\begin{abstract}
In order to understand the causality of instability of chille price in Pekanbaru, which presume has relevanced to the agribusiness system aspect and supply chain condition, a survey with qualitative method is conducted. In fact agribusiness system not yet well established integrally and institutionally, so that none of any form of price cycle control have been persistence for few decades, which fully determine by 'invisible hand' of market mechanism. The source of chilly supply origin scatter from Bukittinggi, West Sumatra, to Middle Java, and even North Sumatra. In 2014 some of the chilli in Pekanbau imported from China, Malaysia and South Korea. Following of rapid growth of Pekanbaru population, the chilli price and chilli farmers could not able to balance it with own chilli development, which actually more developing though with slow pace. The survey get causality linkage of chilly price instability as well as its relevant contribution to inflation rate which relevant to agribusiness system establishment, especially its intituion. The supply chain of chilly in Pekanbaru factually changeable which is an opportunity to chilly farming, trading, and the economy as a whole to tackle inflation. However, organizing and coordinating business actors of chilly establishing and managment of efficient chilly agribusiness system interfere by government in the early stage is a way out, especially concerning chilly price information in the production point, and disseminate it to market or consumer.
\end{abstract}

keywords: cohesiveness, change, supply chain, response, challenge. 


\section{Abstrak}

Untuk memahami hubungan sebab-akibat ketidakstabilan harga cabai di Pekanbaru; yang diperekirakan erat kaitannya dengan disebabkan dari segi system agribisnis dan rantai persediaan (supply chain) suatu penelitian survei denga metoda kualitatif dilakukan. Pada kenyataannya system agribisnis cabai belum terbentuk secara terpadu dan melembaga sehingga tidak ada bentuk pengendalian lonjakan harga yang telah berlangsung berpuluh tahun, yang sepenuhnya ditentukan pasar. Sumber persediaan cabai berasal dari Jawa Tengah, mengganti sumber persediaan dari Sumatera Barat. Bahkan juga pernah diimpor dari China, Malaysia dan Korea seperti pada tahun 2014. Pertumbuhan penduduk Pekanbaru yang pesat tidak mampu diimbangi oleh usaha tani cabai yang sebenanya semakin berkembang di Pekanbaru dalam tingkat yang agak lambat. Difahami secara garis besar hubungan sebab-akibatnya antara ketidakstabilan harga bahkan juga angka inflasi sesaat di Pekanbaru. Keadaan itu erat kaitannya dengan belum mantapnya system agribisnis, terutama kelembagaannya. Rantai persediaan (supply chain) cabai ternyata sudah berubah selaras dengan perubahan meningkatnya penduduk Pekanbaru. Pembentukan dan pengelolaan sistem agribisnis cabai dengan campur tangan pemerintah pada masa awal merupakan jalan keluar.

Kata kunci: keterpaduan, perubahan, rantai persediaan, tanggapan, tantangan.

\section{PENDAHULUAN}

Kebijakan pembangunan pertanian dengan pendekatan agribisnis dicanangkan sejak tahun 1996. Oleh pemerintah didengungkan bahwa pada PJP II (PELITA VI) pertanian dilaksanakan dengan pendekatan agribisnis. Davis dan Goldberg (1957) mendefinisikan agribisnis sebagai:" the sum total of all operations involved in the manufacture and distribution of farm supplies; production on the farm; and the storage, processing and distribution of farm commodities and items made from them." Sungguhpun demikian, pendekatan itu seperti juga berbagai pendekatan sebelumnya, seperti pendekatan produksi juga 
tidak dapat dikatakan berhasil (Boedi Soesilo 1998). Suatu sistem agribisnis dikatakan berjaya manakala harga suatu komoditi stabil, pemasaran efisien, berkat kelembagaannya yang mantap, setidaknya dalam suatu wilayah tertentu (Ahmad 2012).

Produksi cabai di Riau pada tahun 2007 sebanyak 8.137 ton dan menurun jadi 7.609 ton pada tahun 2010, sedangkan pada tahun 2011 diperkirakan naik lagi menjadi 10.504 ton ( BPS dan Dirjen Hortikultura 2010). Persediaan cabai di Riau belum mencukupi permintaan cabainya. Luas lahan tanaman cabai di Pekanbaru misalnya 179 hektar dengan produksi 900 ton/hektar atau produksi per harinya 2,46 ton sedangkan permintaan cabai 4 ton per hari. Oleh karena itu untuk mencukupunya Pekanbaru mengimpor cabai dari Bukittinggi, Jawa dan Sumatera Utara ( Zuprianto 2011).

Keadaan harga cabai di Pekanbaru, setidaknya sejak tahun 1960an selalu dalam keadaan tidak stabil, dengan simpangan turun-naik yang cukup besar, bahkan menjadi satu di antara penyebab terjadinya inflasi. Misalnya pada hari-hari biasa harga cabai sekitar Rp. 15.000 per kilogram; tetapi ketika musim hujan atau akhir tahun dan awal tahun baru harganya mendapai Rp 50.000 per klogram. Bahkan pernah mencapai Rp 150.000 per klogram. Terutama pada hari raya dan bulan puasa, atau di kala akhir tahun dan tahun baru pada tahun 2014. Masalah itulah yang hendak difahami hubungan sebab-akibatnya; dengan praanggapan bahwa keadaan itu erat kaitannya dan disebabkan segi system agribisnis dan rantai persediaan (supply chain).

Akan tetapi, tentang system agribisnis cabai ternyata belum dilakukan penelitiannya selain yang sifatnya pengamatan terhadap subsistem tertentu, khususnya subsistem usaha produksi cabai atau pemasaran cabai saja. Sedangkan bagaimana keadaan subsistem lainnya atau hubungan antar subsistem belum dilakukan penelitiannya. Oleh ssebab itulah maka dilakukan penelitian ini terhadap petani dan pedagang cabai dengan menelusuri pula rantai persedaiaan (supply chain) dari masing-masing subsistem itu. Tujuan penelitian ini ialah untuk mengetahui keadaan system agribisnis cabai dan pengelolaan suply chainnya. Supply Chain Management adalah suatu "proses payung' di mana produk diciptakan dan disampaikan kepada konsumen dari sudut struktural. Suatu rantai persediaan merujuk 
kepada jaringan yang rumit dari hubungan suatu organisasi bisnis dengan rekan bisnisnya untuk yang mempertahankan dan mendapatkan sumber produksi sehingga terjamin dalam menyampaikannya kepada konsumen (Kalakota, 2000, h197). Selanjutnya karena penyediaan cabai di Pekanbaru juga sudah dimasuki oleh cabai luar negeri, maka dibahas pula kemungkinan globalisasi cabai, terutama dengan melibatkan usaha cabai skala kecil sebagai mata rantai persediaan. Tentunya hal itu diawali dengan menuntut peningkatan teknologi produksi, pengelolaan dan pengurusan kegiatan produksi petani cabai.

\section{METODOLOGI PENELITIAN}

Penelitian ini dilakukan di pasar tradisional Pekanbaru pada bulan Agustus-September 2015 menggunakan metoda kualitatif dengan alat pengumpulan data daftar pertanyaan dan pembahasan individual dengan petani dan pedagang cabai.

Sumber data dan informasi ditetapkan contoh secara sengaja (purposive) berdasarkan persetujuan nara sumber yang memberikan data secara sukarela. Para nara sumber berada atau sedang melakukan kegiatan niaga cabai dan berusaha di dan sekitar pasar yang menjadi sasaran survei.Alat pengumpulan data dengan wawancara berpedoman pada daftar pertanyaan yang disiapkan terlebih dahulu.

Analisis data dilakukan dengan menggunakan pedoman sistem agribisnis dan pengelolaan rantai persediaan. Pembahasan diarahkan kepada pencapaian tujuan penelitian sebagai kesimpulan. Sedangkan manfaat penelitian berkaitan erat dengan keadaan bila tercapainya tujuan sekaligus sebagai dasar dalam merumuskan saran.

\section{HASIL DAN PEMBAHASAN}

Keadaan harga cabai di Pekanbaru pada tahun 2014-2017 dapat dilihat seperti pada Tabel 1. Keadaan harga itu menunjukkan tidak stabil dan hubungan antar subsistem belum terpadu. Hal itu dengan mudah terlihat dari 'outcome'nya berupa fluktuasi harga yang kronis seperti terlihat pada Grafik 1. 


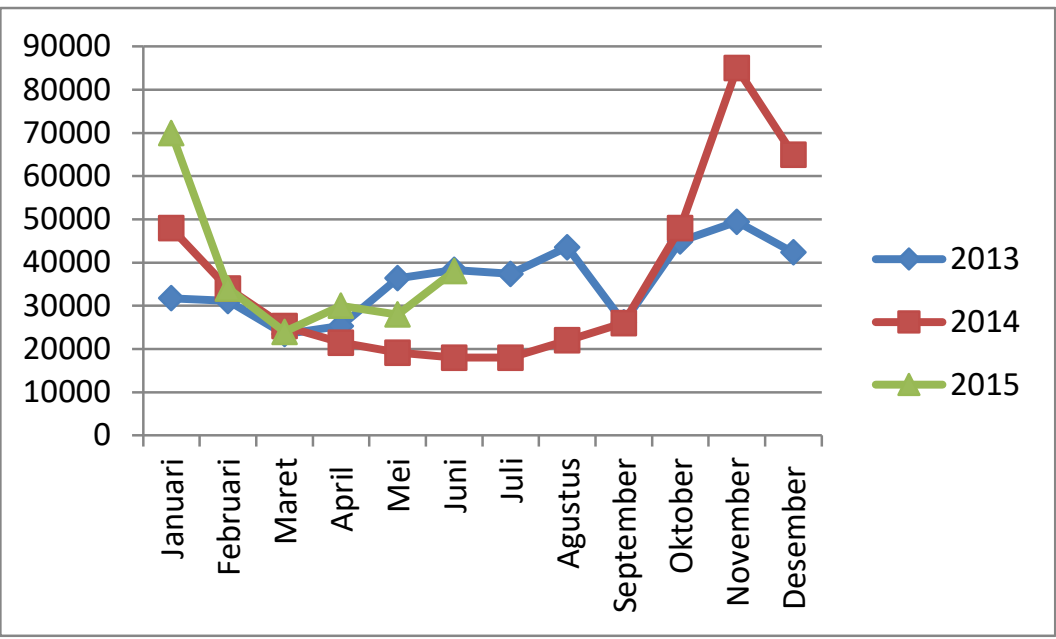

Grafik 1. Harga Cabai 2013-2015.

Akan tetapi, tentang sistem agribisnis cabai ternyata belum tertata sebagai suatu sistem agribisnis yang seimbang antar subsistem, stabil dan terpadu. Hal itu mudah terlihat dari outcome'nya berupa fluktuasi harga yang kronis. Hal itu telah dirasakan konsumen cabai berpuluh tahun. Sungguhpun demikian sistem agribisnisnya belum tertata dan hubungannya belum terbentuk melemaga sebagai suatu sistem agribisnis yang seimbang, terpadu dan berkaitan kuat antar subsistem. Keadaan itu terlah berlangsung berpuluh tahun, telah dirasakan konsumen cabai di Pekanbaru khususnya, bahkan juga di Riau umumnya tanpa ada perubahan yang bermakna teristimewa mengenai harga dan persediaannya.

\section{Biaya Produksi}

Biaya produksi terdiri dari biaya sarana produksi untuk membeli benih, pupuk kandang ayam, dan obata-obatan (fungisida). Juga biaya pengolahan lahan yang terdiri dari sewa bajak dan upah tenaga kerja seperti yang direkam masing-masing pada Tabel 1 dan Tabel 2. 

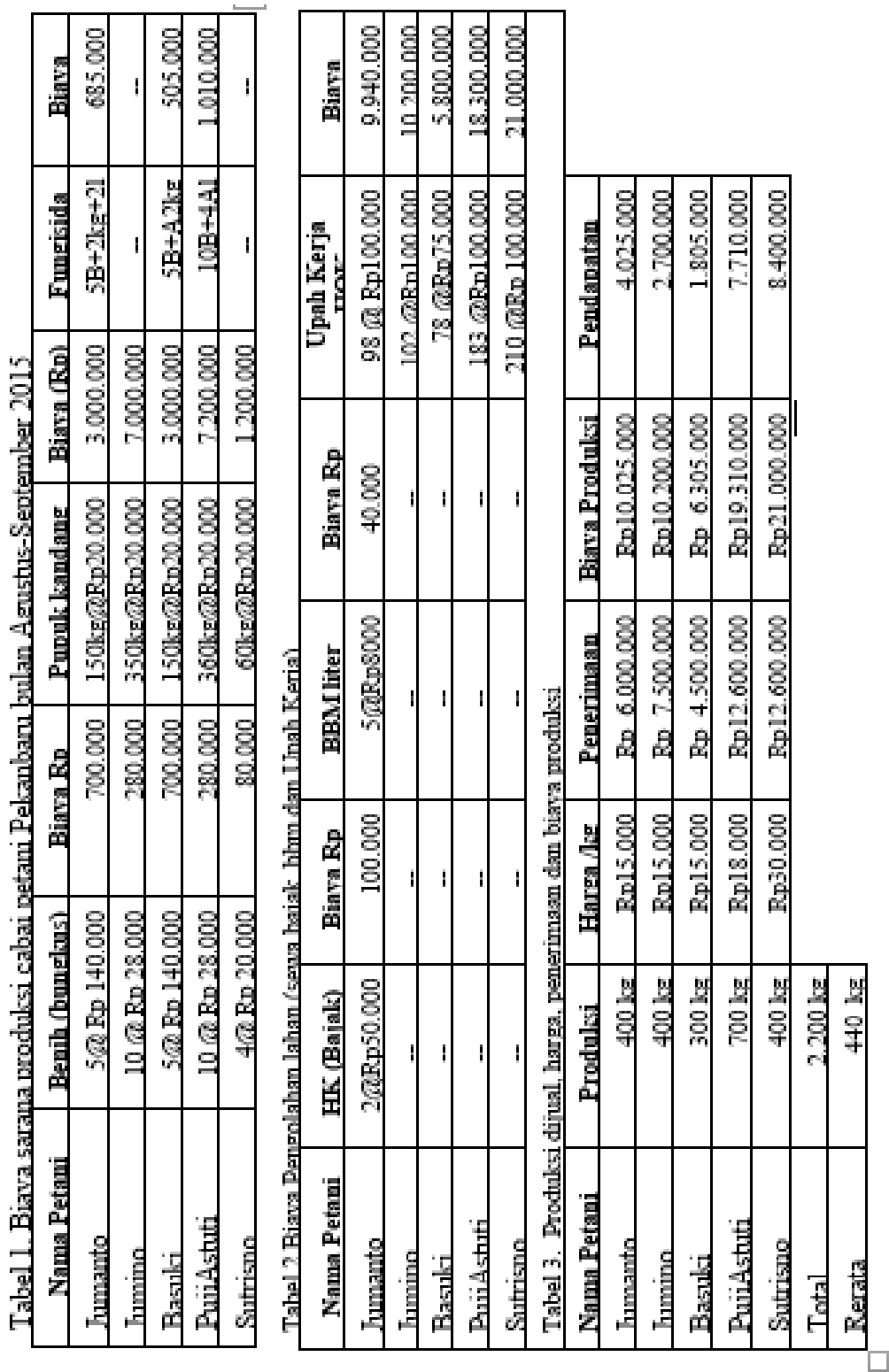


\section{Harga Cabai}

Harga jual oleh petani (farm gate price) atau harga tingkat petani cabai pada Tabel 3 .

\section{Harga Pasar}

Harga pasar (market price) merupakan titik keseimbangan yang merupakan pertemuan antara pembeli dan penjual, yang walaupun adakalannya terjadi tawar menawar, namun keputusan akhir lebih ditentukan pleh penjual (saler market). Tetapi pada tingkat petani pun juga lebih ditentukan oleh pembeli yang biasanya adalah juga pedagang pengumpul (buyer market). Keadaan kedua harga itu dicatat pada Tabel 4.

Tabel 4. Harga pada pedagang pengumpul pada bulan AgustusSeptember 2015

\begin{tabular}{|c|l|c|c|c|}
\hline No & \multicolumn{1}{|c|}{ Pedagang } & $\begin{array}{c}\text { Harga beli } \\
\mathbf{R p} / \mathbf{k g}\end{array}$ & $\begin{array}{c}\text { Harga jual } \\
\mathbf{R p} / \mathbf{k g}\end{array}$ & Margin Rp/kg \\
\hline 1 & Pengumpul 1 & 15.000 & 22.000 & 7.000 \\
\hline 2 & Pengumpul 2 & 15.000 & 22.000 & 7.000 \\
\hline 3 & Pengumpul 3 & 18.000 & 22.000 & 4.000 \\
\hline 4 & Pengecer 1 & 22.000 & 24.000 & 2.000 \\
\hline 5 & Pengecer 2 & 21.500 & 24.000 & 2.500 \\
\hline 6 & Pengecer 3 & 20.000 & 24.000 & 2.000 \\
\hline 7 & Pengecer 4 & 23.000 & 28.000 & 5.000 \\
\hline 8 & Pengecer 5 & 21.000 & 26.000 & 5.000 \\
\hline
\end{tabular}

Harga yang terjadi di pasar baik pada tingkat pedagang pengecer maupun pada tingkat pengumpul sebenarnya disebabkan oleh harga beli dan harga jual. Pada harga jual sudah termasuk dalam biaya timbangan, bubgkusan/kemasan serta biaya lainnya seperti retribusi pasar dan sumbangan lainnya yang dibayar para pedagang. Harga cabai di pasar kota Pekanbaru pada tahun 2013-2015.

Harga yang dibayar konsumen di pasar atau harga beli konsumen pada bulan Agustus-September 2015 adalah dalam rentang Rp23.000 - Rp25.000,- seperti Tabel 5 di bawah: 
Tabel 5. Tabel Harga yang dibayar konsumen pada bulan AgustusSeptember 2015

\begin{tabular}{|c|l|l|}
\hline No & Konsumen & Harga (per kg) \\
\hline 1 & Konsumen 1 & Rp. 23.000 \\
\hline 2 & Konsumen 2 & Rp. 24.000 \\
\hline 3 & Konsumen 3 & Rp. 24.000 \\
\hline 4 & Konsumen 4 & Rp. 24.000 \\
\hline 5 & Konsumen 5 & Rp. 25.000 \\
\hline & Rerata & Rp. 24.000 \\
\hline & Rentang & Rp. $23.000-$ Rp. 25.000 \\
\hline \multicolumn{2}{r}{ Median } & Rp. 24.000 \\
\hline
\end{tabular}

\section{Harga Cabai di Pekanbaru}

Harga cabai pada pasar di Pekanbaru oada tingkat konsumen atau yang dibayar oleh pengguna di Pekanbaru adalah berfluktuasi seperti pada Tabel 5. Pada tahun 2012 keadaan harga cabai merangkak naik pada bulan Mei dan Agustus (kemarau) turun pada bulan September. Tetapi menaik kembali bulan Oktober sampai Januari (musim hujan). Sedangkan pada tahun bergeser menaik pada bulan Oktober sampai Februari tahun berikutnya. Dinamika harga itu dilukiskan pada Grafik 1.

Tabel 5. Harga Cabai per bulan di Pekanbaru 2013-2014

\begin{tabular}{|c|l|c|c|c|}
\hline \multirow{2}{*}{ No } & \multirow{2}{*}{ Bulan (Harga Rp/kg) } & \multicolumn{3}{|c|}{ Tahun } \\
\cline { 3 - 5 } & & $\mathbf{2 0 1 3}$ & $\mathbf{2 0 1 4}$ & $\mathbf{2 0 1 5}$ \\
\hline 1 & Januari & 31.740 & 47.962 & 70.000 \\
\hline 2 & Februari & 31.121 & 34.002 & 34.000 \\
\hline 3 & Maret & 23.462 & 25.267 & 24.000 \\
\hline 4 & April & 25.348 & 21.473 & 30.000 \\
\hline 5 & Mei & 36.392 & 19.164 & 28.000 \\
\hline 6 & Juni & 38.291 & 17.991 & 38.000 \\
\hline 7 & Juli & 37.376 & 18.000 & \\
\hline 8 & Agustus & 43.574 & 22.000 & \\
\hline 9 & September & 26.167 & 26.000 & \\
\hline 10 & Oktober & 44.917 & 48.000 & \\
\hline
\end{tabular}




\begin{tabular}{|l|l|l|l|l|}
\hline 11 & November & 49.458 & 85.000 & \\
\hline 12 & Desember & 42.361 & 65.000 & \\
\hline
\end{tabular}

Sumber : riaubisnis.com

\section{Sistem Agribisnis}

Permintaan konsumen terhadap komoditi cabai semakin meningkat seiring dengan meningkatnya penduduk. Sesuai dengan berjalannya waktu, hal itu ditandai dengan tingginya tingkat impor yang diartikan sebagai lemahnya petani di Indonesia dalam memproduksi komoditas pertanian, sehingga hasil dari produksi tersebut tidak dapat memenuhi kebutuhan masyarakat. Sektor pertanian merupakan pilar utama pembangunan bangsa Indonesia.

Hampir seluruh kegiatan perekonomian Indonesia berpusat pada sektor pertanian. Hal tersebut dapat dilihat dalam pembentukan PDB, penerimaan devisa, penyerapan tenaga kerja, penyediaan pangan, dan penyediaan bahan baku industri. Belajar dari pengalaman masa lalu dan kondisi yang dihadapi saat ini, sudah selayaknya sektor pertanian menjadi sektor unggulan dalam menyusun strategi pembangunan nasional. Pola konsumsi masyarakat atas berbagai produk pertanian yang semakin hari semakin meningkat serta pertumbuhan penduduk Indonesia yang semakin meningkat hingga mencapai 240 juta jiwa, sangat mempengaruhi ketersediaan pangan dan pemenuhan kebutuhan pangan masyarakat Indonesia (Kompasiana, Sabtu 21 Desember 2013).

Kelemahan agribisnis nasional disebabkan oleh struktur agribisnis dispersial yang dicirikan oleh tidak adanya hubungan organisasi fungsional antara subsistem off-farm hulu dengan on-farm, antara onfarm dengan off-farm hilir dan dengan subsistem supporting institution. Dan kelemahan selanjutnya adalah struktur yang asimetris dengan ciri adanya ketimpangan kekuatan antar subsistem agribisnis. Kemudian kelemahan selanjutnya yaitu petani, yang umumnya berada pada on-farm agribisnis menderita tekanan exploitasi monopsonistis dan exploitasi monopolistik (Saragih, 1996).

Konsep agribisnis pada dasarnya melihat usaha pertanian sebagai suatu bisnis, suatu usaha komersial yang bertujuan mendapatkan 
keuntungan. Bukan untuk sekedar cukup makan atau bertahan hidup (subsistence). Karena itu kegiatan tersebut harus berorientasi kepada keuntungan dengan menekan resiko sekecil mungkin dan efisiensi pemasaran. Hal ini dapat dilakkukan dengan melihat suatu persoalan secara menyeluruh (sistem), dengan pemahaman bahwa terdapat saling keterkaitan antara subsistem yang satu dengan subsistem yang lain. Sistem agribisnis paling tidak mencakup subsistem input produksi, subsistem produksi atau budidaya, subsistem pengolahan atau agroindustri dan subsistem pemasaran atau distribusi. Dalam rangka memperkecil resiko pada usaha agribisnis maka semua subsistem ini harus dilihat secara cermat sehingga perencanaan kegiatan pada suatu subsistem sedapat mungkin sudah dihitung berdasar-kan kinerja yang ada pada subsistem lainnya. Misalnya perencanaan luas tanaman (subsitem produksi), perlu melihat kondisi pasar yang diperkirakan bisa diraih (subsitem pemasaran), kemampuan peralatan pengolahan (subsistem pengolahan) serta perlu juga menyiapkan bibit yang baik serta lahan yang tersedia (subsistem input produksi) (Subiyanto, 1996).

Permasalahan dalam sistem agribisnis juga terlihat pada perniagaan cabai. Seperti yang diketahui jumlah komoditas cabe yang ada di Indonesia khususnya di wilayah Pekanbaru tidak lagi mencukupi kebutuhan masyarakat. Rantai persediaan terbentuk dan berkembang secara alamiah namun belum menyintuh pemantapan sistem agrbisnesnya. Pelaku niaga dalam kegiatan agribisnis cabai di Indonesia dapat dikelompokkan atas petani, pedagang (pengumpul, grosir, dan import/ekspor-tir), industri pengolah bahan makanan, konsumen rumah tangga dan lembaga (rumah makan dan hotel), serta pemerintah belum berperanan secara terpadu dalam rantai yang ada. Masing-masing mempunyai peran dan kepentingan yang berbeda, yang dalam hal-hal tertentu kepentingan tersebut dapat bersifat saling bertentangan (conflict). Walaupun pemerintah tidak secara langsung berperan sebagai pelaku ekonomi, tetapi pemerintah mengkondisikan bagi berlangsungnya kegiatan agribisnis cabe melalui berbagai macam kebijakkan dan penyediaan infrastruktur, dengan maksud agar mekanisme pelaksanaan agribisnis cabai dapat berlangsung secara adil bagi semua pelaku ekonomi yang terlibat dan terjadi berkesinambungan. Dengan perkataan lain, pemerintahlah yang 
bertindak sebagai lembaga ataupun membangun lembaga yang mengelola kelembagaan dalam sistem agribisnis cabai.

\section{Rantai Persediaan}

Pengelolaan Rantai Persediaan (Supply Chain Management) adalah suatu 'proses payung' di mana produk diciptakan dan disampaikan kepada konsumen dari sudut struktural. Suatu rantai persediaan merujuk kepada jaringan yang rumit dari hubungan suatu organisasi bisnis dengan rekan bisnisnya untuk yang mempertahankan dan mendapatkan sumber produksi sehingga terjamin dalam menyampaikannya kepada konsumen (Kalakota, 2000, h197). Persediaan benih cabai dan pupuk serta obatan dalam memproduksi cabai diperoleh petani dari pedagang setempat, tetapi semua bahan itu didatangkan dari pelbagai kota di Jawa dan Sumatera.

Misalnya benih cabai dan obatan hama dan penyakit didatangkan dari Jawa atau Medan, sedangkan pupuk kandang (organik) didatangkan dari Sumatera Barat (Payakumbuh) selain dari kandang ayam yang ada di sekitar Pekanbaru dalam jumlah yang terbatas. Sedangkan aupply pupuk cair umumnya didatangkan dari Jawa atau Medan.

Tujuan yang hendak dicapai dari setiap rantai persediaan adalah untuk memaksimalkan nilai yang dihasilkan secara keseluruhan (Chopra, 2001). Rantai persediaan yang terpadu akan meningkatkan keseluruhan nilai yang dihasilkan oleh rantai persediaan tersebut. Supply-chain cabai, baik cabai rawit maupun cabai merah di datangkan dari luar, terutama pada awalnya cabai keriting di datangkan dari Bukittinggi, tetapi belakangan ini cabai merah kriting dan sawitpun sebagian sudah didatangkan dari Jawa dan Sumatera Utara (Karo dan Tapanuli). Daerah itu punya pengalaman sebagai penyedia sayur dan cabai ke Riau maupun ke luar negeri, terutama Singapura dan Malaysia. Itu berarti upaya ke arah memadukan petani kecil ke pasar global, yang strategi untuk menghadapi tantangannya dapat dirumuskan.

Strategi utama haruslah memperkuat sistem agribisnis dan kelembagaannya yang inklusif para produksi pangan kecil; memajukan agribisnis melalui perbaikan teknologi dan pengelolaan; 
memelihara keterbukaan keterkaitan sukarela ke pasar dalam negeri dan global ke perusahaan peerdagagan; dengan memperkaya efisiensi dalam alokasi sumberdaya; penelitian dan pengem-bangan inovativ dan inventiv pada pertanian pangan skala kecil (Sarmi, Gultom, Mardaleni, 2013; diikuti dengan kebijakan yang berfihak terehadap penghasil pangan kecil. Secara domestik maupun regional, suatu kerjasama produktif dan nyata dalam tindakan terpadu di antara dan di dalam pemangku kepentingan, seperti para petani, perusahaan perdagangan, para peneliti, LSM, dan pelayanan penyuluhan, akan menolong para penghasil pangan kecil memajukan niaga dan kehidupannya (Fatimah dan Ahmad 2012).

Kemudahan memperoleh persedaiaan dari luar daerah itu, terutama karena komunikasi yanag semakin lancar, terutama transportasi umum dara menggunakan truk dan bus umum. Barangbarang yang diperlukan itu dipesan dengan menggunakan ICT baik melalui telepon genggam maupun melalui internet. Pesanan pedagang pengumpul maupun eceran dilakukan melalui komunikasi itu dan mereka menunggu barang di stadiun truk atau terminal bus, terutama cabai basah maupun kering. Dengan demikian perdagangan cabai sedang berkembang memasuki Ekonomi digital atau e-commerce yang semula atas inisiatif para pedagang cabai sendiri secara individu dan belakangan ini bahkan juga didukung oleh pemerintah. Sesungguhnya dengan perkembangan itu pemerintah dapat membina kelembagaan sistem agribisnis cabai yang bertujuan membangun sistem agribisnis yang efisien, efektif, berimbang, terpadu dan memaksimalkan nilai keseluruhan sistem agribisnis cabai itu. Menurut Indrajit dan Djokopranoto (2006), beberapa manfaat dari pengelolaan pasokan antara lain adalah sebagai berikut :

1. Mengurangi simpanan persediaan (inventori) barang. Simpanan persediaan merupakan bagian paling besar dari aset perusahaan yang menapai sekitar 30-40\%. Sedangkan biaya permintaan barang berkisar antara $20-40 \%$ dari nilai barang yang disimpan. Oleh karena itu, usaha dan cara harus dikembangkan untuk menekan penimbunan barang.

2. Menjamin kelancaran barang. Kelancaran barang perlu dijamin mulai dari barang asal (sumber awal, produsen) sebagai pemasok, 
pengumpul, penjual eceran, sampai kepada final customer. Jadi, rangkaian perjalanan dari bahan baku sampai menjadi barang jadi diterima oleh pengguna/ pemakan merupakan rantai yang perlu dikelola dengan baik yang dapat dilukiskan seperti pada Gambar 2. Rantai pasokan antar lembaga atau organisasi pemasaran di Pekanbaru. Pada setiap organisasi subsistem agribisnis sebagai rantai penyediaan terlihat hubungan timbal balikpergerakan bahan cabai, informasi dan nilai tunai uang berkaitan. Semuanya terkesan digarakkan oleh mengalirnya informasi timbal-balik antara penyedia (supplier) dengan pengguna (customer).

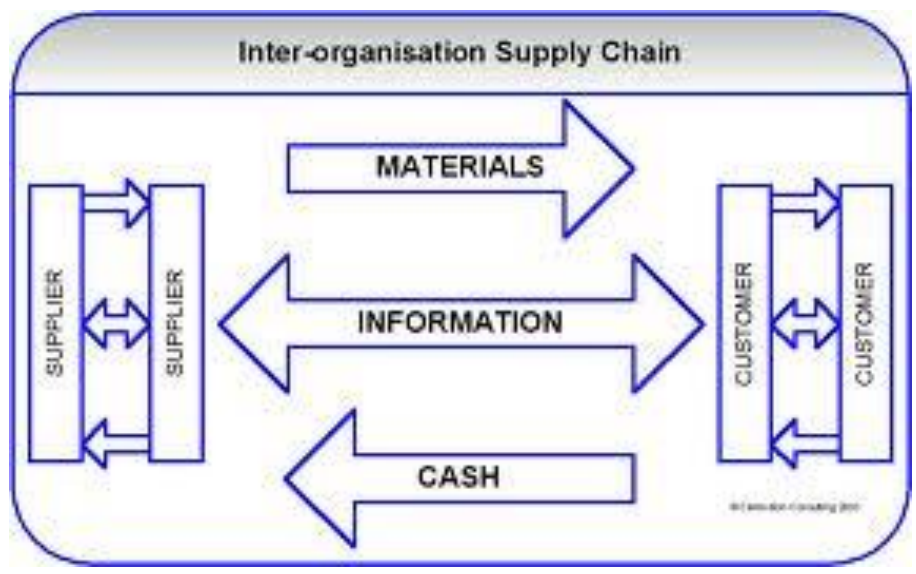

Gambar 2. Rantai pasokan antar lembaga atau organisasi pemasaran.

3. Menjamin mutu. Mutu barang ditentukan tidak hanya oleh proses produksi barang tersebut, tetapi juga oleh mutu barang mentahnya, penanganan dan mutu keamanan pengirimannya. Jaminan mutu ini juga merupakan serangkaian mata rantai panjang yang harus dikelola dengan baik.

4. Resiko dan pengelolaannya (Chopra, dan Meindl. 2001). Sebenarnya pengelolaan risiko memainkan suatu peranan vital dalam kemangkusan pengelolaan operasi rantai pasokan. Sungguhpun demikian pada perdagangan cabai di Pekanbaru hal itu tidak terungkap dalam kaitannya dengan harga, walaupun menghadapi pelbagai macam ketidak pastian berkenaan pasokan. 
Oleh sebab itu, suatu risiko yang rinci berkenaan dengan risiko rantai pasokan yang dihadapi perdagangan cabai perlu dikaji. Antara lain adalah berkenaan persediaan pasokan cabai dengan rumusan pemahaman yang berkaitan dengan risiko, jenis dan bentuk risiko, serta faktor risiko dan akibat maupun jaminan risiko cabai. Apalagi dalam rangka menjamin persediaan beras pemerintah telah memberikan subsidi asuransi kepada para petani padi. Merujuk pada asuransi petani padi itu, maka untuk stabilisasi harga cabai dan menekan inflasi yang disebabkan oleh cabai di Riau dan kronis kenaikan harga cabai serta untuk meransang para petani cabai tempatan, maka perlu dipertimbangkan untuk memberikan asuransi petani cabai di Riau tersebut.

\section{KESIMPULAN}

Telah difahami secara garis besar hubungan sebab-akibatnya antara ketidakstabilan harga bahkan juga angka inflasi di Pekanbaru erat kaitannya dengan rantai dan masa persediaan cabai. Keadaan itu erat kaitannya dengan disebabkan oleh belum mantapnya aspek system agribisnis cabai, terutama kelembagaannya.

Rantai persediaan (supply chain) cabai ternyata sudah berubah selaras dengan perubahan meningkatnya penduduk Pekanbaru, di antaranya mulai dengan penggunaan alat komunikasi (ICT) dalam rantai persediaan sedang memasuki 'e-commerce' dan digital ekonomi.

Oleh karena itu kajian lanjutan mengenai rantai persediaan dalam agribisnis dan intensitas niaga elektronik dan digital ekonomi merupakan keniscayaan dalam memahami dan mengembankan. system agribisnis cabai.

Untuk stabilisasi harga cabai dan menekan inflasi yang disebabkan oleh cabai di Riau mengingat kronisnya ketidakpastian harga cabai serta bagi meransang para petani cabai tempatan, maka selain kebijakan peningkatan produksi cabai, juga perlu dipertimbangkan untuk memberikan asuransi petani cabai di Riau tersebut. 


\section{DAFTAR PUSTAKA}

Ahmad, Mukhtar dan U.P. Ismail 2015. Kemelut Cabai dan Memahami Agribisnis Cabai. Koran Riau.

BPS dan Dirjen Hortikultura 2010. Produksi cabai besar menurut Provinsi. Online pada: http://www.deptan.go.id/infoeksekutif/hortikultura/eishorti/Produksi\%20Cabe\%20Besar.pdf diakses pada tanggal 20 Mei 2012.

Boedi Soesilo 1998. Makalah yang disampaikan pada Pertemuan Pemantapan Program dan Proyek Tahun Anggaran 1998/1999 di Solo.

Chopra, S. and Meindl, P. 2001. Supply chain management: Strategy, planning, andoperations. New Jersey, USA: - Prentice Hall.

Davis, J.H. dan Ray A. Goldberg (1957)A Concept of Agribusiness, Boston: Division of Research, Graduate School of Business Administration, Harvard University, 1957.

Fatimah, Sri and Mukhtar Ahmad 2012. Strategy of Integrating Agriffood Small Producers into Globalizing Food Chains: Case of Greater Bandung Vegetables Producers. Paper submitted to the 4th Agribusiness Economics Conference"Globalizing Food Chains and the Emerging Economies" 10-11 July 2012, Davao City, The Philippines.

Indrajit, R.E dan R. Djokopranoto 2006. Konsep manajemen supply chain: Cara baru memandang mata rantai penyediaan barang. Grasindo. Yogyakarta.

Kalakota, R. 2000. E-Business 2.0: A Roadmap to Success. Longman: Addison Welley, USA.

Kompasiana, Sabtu 21 Desember 2013.

Saragih, Bungaran. 1996. 'Peningkatan Keunggulan Daya Saing Agribisnis Memasuki Era Persaingan Global,' Analisis Sistem No.7(3):159-160 
Sarmi Julita, Hecules Gultom, Mardaleni, 2013. Pengaruh Pemberian Mikroorgnisme Lokal (MOL) Nasi dan Hormon Tanaman Unggul Terhadap Pertumbuhan dan Produksi Tanaman Cabai (Capsicum annum L.) Jurnal Dinamika Pertanian Volume XXVIII Nomor 3 Desember 2013 (167-174).

Subiyanto, 1996. 'Analisis Fluktuasi Harga dan Kecukupan Komoditas Cabe Nasional,' Analisis Sistem No.7(3):188-190. 186-187

Turban, E., King, D., Mckay, J., Marshall, P., Lee, J., \& Viehland, D. (2008). Electronic Commerce 2008 a managerial perspective. New Jersey: Pearson Education, Inc.

Zuprianto 2012. Produksi Cabe Riau Belum Cukup Penuhi Permintaan. Online pada http://riaubisnis.com/index.php/agriculture-mainmenu 109/42 pertanian /2434-produksi-cabe- riau-belum-cukup-penuhipermintaan? tmpl=component\&print=1\&page diakses pada tanggal 22 Maret 2012. 